\title{
USE OF REAL OPTIONS THEORY
}

\author{
KREMLJAK, Z. \& HOCEVAR, M.
}

Abstract: Real option is an alternative or choice that becomes available with a business investment opportunity. Real options can include opportunities to expand and cease projects if certain conditions arise, amongst other options. They are referred to as "real" because they usually pertain to tangible assets such as capital equipment, rather than financial instruments. Taking into account real options can greatly affect the valuation of potential investments. Oftentimes, however, valuation methods, such as NPV, do not include the benefits that real options provide. Real option is not a derivative instrument, but an actual option that a business may gain by undertaking certain endeavours.

In this contribution, the real option theory is applied in the case of investment in the a factory for heating equipment by using Net Present Value (NPV), alternative prognosis of changing exchange rates, capital investments and currency speculations.

Key words: Real Option, Application, Net Present Value, Scenario, Investment
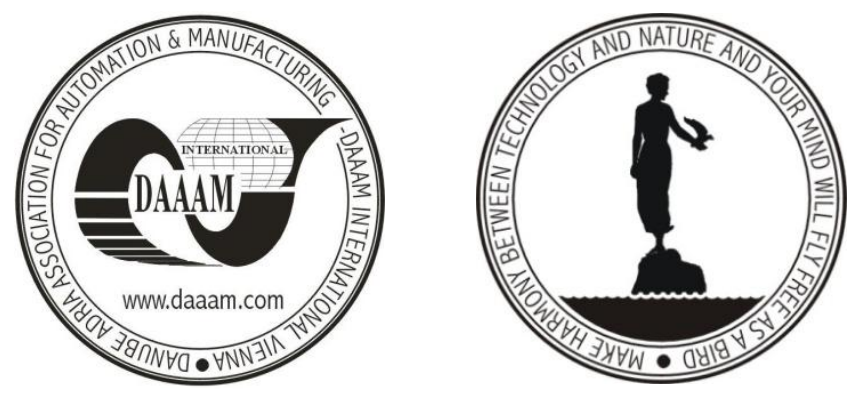

Authors' data: Assistant Prof. Dr. Sc. Kremljak, Z[vonko]*; Full Prof. Dr. Sc. Hocevar, M[arko]**, *Telekom Slovenije, d. d. Cigaletova 15, SI - 1000 Ljubljana, Slovenia, European Union, **University of Ljubljana, Faculty of Economics, Kardeljeva ploscad 17, SI - 1000 Ljubljana, Slovenia, European Union, zvonko.kremljak@s5.net, marko.hocevar@ef.uni-lj.si

This Publication has to be referred as: Kremljak, Z[vonko] \& Hocevar, M[arko] (2013) Use of Real Options Theory, Chapter 15 in DAAAM International Scientific Book 2013, pp. 329-338, B. Katalinic \& Z. Tekic (Eds.), Published by DAAAM International, ISBN 978-3-901509-94-0, ISSN 1726-9687, Vienna, Austria DOI: $10.2507 /$ daaam.scibook.2013.15 


\section{Introduction}

A real option is the right (but not the obligation) to undertake certain business initiatives, such as deferring, abandoning, expanding, staging, or contracting a capital investment project. For example, the opportunity to invest in the expansion of a firm's factory, or alternatively to sell the factory, is a real call or put option, respectively. Real options are generally distinguished from conventional financial options in that they are not typically traded as securities, and do not usually involve decisions on an underlying asset that is traded as a financial security. Real options analysis, as a discipline, extends from its application in corporate finance, to decision making under uncertainty in general, adapting the techniques developed for financial options to real-life decisions. It forces decision makers to be explicit about the assumptions underlying their projections and for this reason real options valuation (ROV) is increasingly employed as a tool in business strategy formulation (Howell et al., 2001). Although there is much similarity between the modelling of real options and financial options, ROV is distinguished from the latter, in that it takes into account uncertainty about the future evolution of the parameters that determine the value of the project, coupled with management's ability to respond to the evolution of these parameters $(* * *, 2013)$.

The research work of Black, Scholes and Merton led to a method which enabled appropriate valuation of options in conditions of uncertainty. This resulted in a huge growth of research in the field of financial assets valuation. The possibility of valuation of the so-called financial options was interesting not only for the academics but it was also accepted by the business systems as well.

\subsection{Types of Real Options}

The flexibility available to management will relate to project size, project timing, and the operation of the project once established.

- Options relating to project size:

- Option to expand: Here the project is built with capacity in excess of the expected level of output so that it can produce at higher rate if needed. Management then has the option (but not the obligation) to expand should conditions turn out to be favourable. A project with the option to expand will cost more to establish, the excess being the option premium, but is worth more than the same without the possibility of expansion. This is equivalent to a call option.

- Option to contract: The project is engineered such that output can be contracted in future should conditions turn out to be unfavourable. Forgoing these future expenditures constitutes option exercise. This is the equivalent to a put option, and again, the excess upfront expenditure is the option premium.

- Option to expand or contract: Here the project is designed such that its operation can be dynamically turned on and off. Management may shut down part or all of the operation when conditions are unfavourable (a put option), and may restart operations when conditions improve (a call option). This option is also known as a switching option. 
- Options relating to project life and timing:

- Initiation or deferment options: Here management has flexibility as to when to start a project. This constitutes an American styled call option.

- Option to abandon: Management may have the option to cease a project during its life, and, possibly, to realise its salvage value. Here, when the present value of the remaining cash flows falls below the liquidation value, the asset may be sold, and this act is effectively the exercising of a put option.

- Sequencing options: This option is related to the initiation option above, although entails flexibility as to the timing of more than one inter-related projects: the analysis here is as to whether it is advantageous to implement these sequentially or in parallel. Here, observing the outcomes relating to the first project, the firm can resolve some of the uncertainty relating to the venture overall. Once resolved, management has the option to proceed or not with the development of the other projects. If taken in parallel, management would have already spent the resources and the value of the option not to spend them is lost.

- Options relating to project operation:

- Output mix options: The option to produce different outputs from the same facility is known as an output mix option or product flexibility. These options are particularly valuable in industries where demand is volatile or where quantities demanded in total for a particular good are typically low, and management would wish to change to a different product quickly if required.

- Input mix options: An input mix option (process flexibility) allows management to use different inputs to produce the same output as appropriate.

- Operating scale options: Management may have the option to change the output rate per unit of time or to change the total length of production run time, for example in response to market conditions. These options are also known as intensity options.

\section{Option Thinking}

Let us take a look into the basic logics of option thinking (Fig. 1) on a simple investment evaluation example.

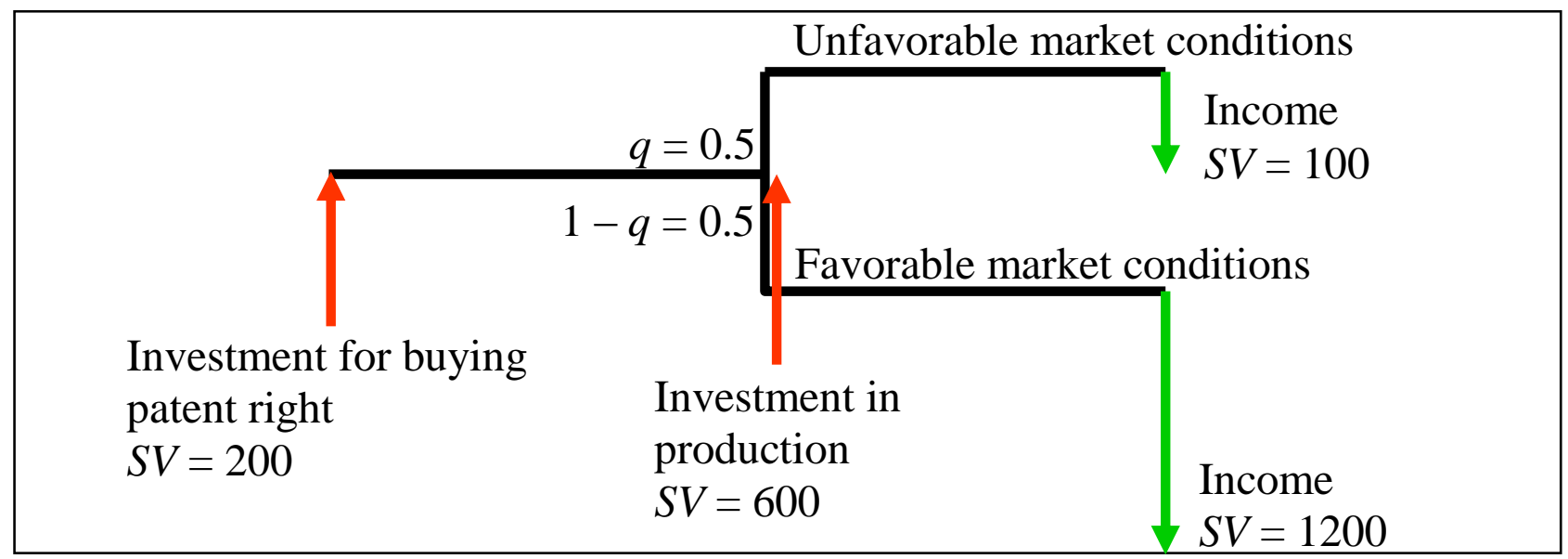

Fig. 1. Simple example of option valuation 
If we make a small initial investment, for instance, buying a patent right. Such investment creates a certain option, which can be used in a given period. The second stage id the investment in production. In case of realized second stage, there is a possibility that the project creates either a high of a low cash flow, depending on the market conditions. Let us suppose that the likelihood for occurrence of both situations is equal.

With a classical Net Present Value (NPV) analysis, it is assumed that the second stage of the project shall be definitely realized, irrespective of the development of events in the future. If we calculate the net present value of the project:

- static $N P V=-200-600+(0.5 \times 100+0.5 \times 1200)$

- static $N P V=-150 \rightarrow$ project is rejected.

So, a negative net present value is obtained, which means the project, according to the classical investment valuation method, is not attractive.

Let us now include the optional logic, based on which the option will not necessarily be realized. So, the implementation of the second stage of the project is not binding. The decision for making an investment in production equipment (option) was adopted based on the current market situation:

- extended $N P V=-200+0.5 \times \max (100-600,0)+0.5 \times \max (1200-600,0)$

- extended $N P V=100 \rightarrow$ project is accepted (includes the option value).

The gap between finance and corporate strategy remains embarrassingly large. Taking into account the optional logic, we can see that this investment opportunity is still topical. Therefore, it is of crucial importance, when assessing the project, to take into consideration the possible included options, because otherwise a potential bearing project can be rejected (Luehrman, 1998).

Let us highlight once again the real options advantages compared to traditional methods of valuing investments. In approaches based on discounted cash flow methods it is assumed that the management makes decisions based on the specific operational strategies and insists on them until the end of predetermined project life, even though the future is uncertain (Adner \& Levinthal, 2004). Therefore, these methods do not take into account the additional value that has the potential to change the flow of investments. Such intervention of the management during the project implementation and the adoption of operational decisions in compliance with the changes in the market conditions provides the company with the opportunity for gaining higher profits and minimizing loss (Dixit \& Pindyck, 1995). If we assume passive implementation of certain operating strategy, then, the methods of discounted cash flows tend to underestimate the investment value (Yeo \& Qiu, 2003). In essence, the $N P V$ approach takes into account several unconditional assumptions regarding the expected scenario of cash flows. Projects are treated as isolated (independent) investment opportunities that are adopted in case the calculated $N P V$ is positive. Also, the DCF approach assumes inflexibility of the management which insists on a specific operating strategy for project completion. This is, of course, only an assumption, which is not a reflection of the real situation. 
Until now, the real options theory was applied in different areas. Mun (2010) gives the concepts of real options use and their impact on business decisions and strategy in conditions of uncertainty and risk. Miler and Park (2002) divided the existing applications of real options theory in the following fields:

- Biotechnology,

- Planning of production and means of production,

- Research and Development,

- Technology,

- Natural resources,

- Strategy,

- Securities.

Focusing on the use of real options for valuation of manufacturing flexibility, we can identify a multitude of applications. Kulatilaka (1993) develop a model to determine the value of an option that comes with a choice of two operating options. Kulatilaka and Trigeorgis (1994) presented the analysis of generic flexibility of selection between alternative technologies. Dasu and Li (1997) develop the structure of optimal conduct of companies haing plants in different countries, where the relative costs of production plants change over time. Kouvelis (1999) analyzes the mechanisms of selection of suppliers taking into account the changes in demand. Nembhard and Aktan (2009) value real options included in the possibility that part of the production operations are outsourced to external service providers. Mauer and Ott (1995) value the possibility of exchange, taking into account the uncertainty of operating costs, the procurement costs and the technological uncertainty. Bollen (1999) uses the real options principle for valuation of the product life cycle. The use of real options for assessment of the value of flexibility in the management of technological R\&D programs is shown by Siddiqui (2012). Within the real options concept we must evaluate the possibility of diverting the surplus of production capacities from one product to another. Collana, Fuller and Mezei (2009) present the new method of real options valuation using fuzzy numbers, which is easier to understand and less complex than the previous theories of valuation. Jaimungal and Lawryshyn (2012) provide an indicator of the market sector, which enabled linking of assessment of cash flow and real options theory (very important in the early stages of investment projects), which does not apply in practice.

\subsection{Other Fields of Real Options Applications}

Real options are also useful as a strategic business tool in capital investment decisions (Bowman \& Moskowitz, 2001). For instance, should a firm invest millions in a new e-commerce initiative?

How does a firm choose among several seemingly cashless, costly, and unprofitable information technology infrastructure projects? Should a firm invest its billions in a risky research and development initiative? The consequences? However, real-life business conditions are a lot more complicated. Your firm decides to go with an e-commerce strategy, but multiple strategic paths exist. Which path do you choose? What are the options you have? If you choose the wrong path how do you 
get back on the right track? How do you value and prioritize the paths that exist? You are a venture capitalist firm with multiple business plans to consider (Mun, 2010).

How do you value a start-up firm with no proven track record? How do you structure a mutually beneficial investment deal? What is the optimal timing to a second or third round of financing? Real options are useful in valuing a firm through its strategic business options. A wrong decision can be disastrous or even terminal for certain firms (Kyläheiko et al., 2001). For example, by investing in a particular project, a company may have the real option of expanding, downsizing or abandoning other projects in the future. Other examples of real options may be opportunities for $\mathrm{R} \& \mathrm{D}, \mathrm{M} \& \mathrm{~A}$ and licensing.

In a traditional discounted cash flow model, these questions cannot be answered with any certainty. In fact, some of the answers generated through the use of the traditional discounted cash flow model are flawed because the model assumes a static, one-time decision-making process, whereas the real options approach takes into consideration the strategic managerial options certain projects create under uncertainty and management's flexibility in exercising or abandoning these options at different points in time, when the level of uncertainty has decreased or has become known over time (Smit \& Trigeorgis).

The real options approach incorporates a learning model, such that management makes better and more informed strategic decisions when some levels of uncertainty are resolved through the passage of time. The discounted cash flow analysis assumes a static investment decision and assumes that strategic decisions are made initially with no recourse to choose other pathways or options in the future (Pandza et al., 2003). To create a good analogy of real options, visualize it as a strategic road map of long and winding roads with multiple perilous turns and branches along the way. Imagine the intrinsic and extrinsic value of having such a road map or global positioning system when navigating through unfamiliar territory, as well as having road signs at every turn to guide you in making the best and most informed driving decisions (Trigeorgis, 2002). Such a strategic map is the essence of real options. The answer to evaluating such projects lies in real options analysis, which can be used in a variety of settings, including pharmaceutical drug development, oil and gas exploration and production, manufacturing, start-up valuation, venture capital investment, information technology infrastructure, research and development, mergers and acquisitions, e-commerce and e-business, intellectual capital development, technology development, facility expansion, business project prioritization, enterprise-wide risk management, business unit capital budgeting, licenses, contracts, intangible asset valuation, and the like (Mun, 2010).

\section{Example in Practice, using the Net Present Value (NPV)}

There are four components in the manager's toolkit for valuing investment opportunities: payback rules, accounting rates of return, net present values $(N P V)$ and real options. To implement $N P V$, we need estimates of expected future cash flows and an appropriate discount rate. And there's the rub. An NPV calculation only uses information that is known at the time of the appraisal. 
A heating equipment manufacturer is considering the possibility for opening a factory in Japan. The construction of the factory would cost 1.3 million yen, and in the next 7 years, it would generate cash flows in amount of 200,000 yen.

Other available information:

- The interest rate for JPY: $2.9 \%$.

- The interest rate for CAD: $8.75 \%$.

- Exchange rate: JPY / CAD: 83.86.

- Assumption: The investment is not risky.

How to calculate $N P V$ ?

\subsection{Calculation of the Net Present Value under two methods}

\section{- Method I}

- Step 1: The cash flow is projected in JPY.

- Step 2: The exchange rate for JPY is discounted, $N P V$ in JPY is obtained.

- Step 3: $N P V$ is translated from yen to Canadian dollars under the current exchange rate, we get $N P V$ in CAD.

\section{- Method II}

- Step 1: The cash flow is projected in JPY.

- Step 2: The cash flows are translated in CAD under the expected forward rate.

- Step 3: The cash flows in CAD are discounted with interest rate for CAD, we get $N P V$ of CAD.

Method I: Present value $=-49.230$ yens.

Method II: Present value $=-590 \mathrm{CAD}=(590 * 83,86)$ yens $=-49.230$ yens.

Both methods produce the same result!

\begin{tabular}{|c|c|c|c|c|c|c|c|c|}
\hline Year forward rate & $\begin{array}{c}2013 \\
83,86\end{array}$ & $\begin{array}{c}2014 \\
79,35\end{array}$ & $\begin{array}{c}2015 \\
75,08\end{array}$ & $\begin{array}{c}2016 \\
71,04\end{array}$ & $\begin{array}{l}2017 \\
67,22\end{array}$ & $\begin{array}{l}2018 \\
63,61\end{array}$ & $\begin{array}{l}2019 \\
60,18\end{array}$ & $\begin{array}{r}2020 \\
59,95\end{array}$ \\
\hline \multicolumn{9}{|l|}{ Method I } \\
\hline $\begin{array}{l}\text { Cash flow (Yen) } \\
\text { Discount factor (Yen) } \\
P V(\text { Yen })\end{array}$ & $\begin{array}{c}-1300 \\
1,000 \\
-1300,000\end{array}$ & $\begin{array}{c}200 \\
0,972 \\
194,363\end{array}$ & $\begin{array}{c}200 \\
0,944 \\
188,886\end{array}$ & $\begin{array}{c}200 \\
0,918 \\
183,562\end{array}$ & $\begin{array}{c}200 \\
0,892 \\
178,389\end{array}$ & $\begin{array}{c}200 \\
0,867 \\
173,362\end{array}$ & $\begin{array}{c}200 \\
0,842 \\
168,476\end{array}$ & $\begin{array}{c}200 \\
0,819 \\
163,728\end{array}$ \\
\hline \multicolumn{9}{|l|}{ Method II } \\
\hline $\begin{array}{l}\text { Cash flows }(\mathrm{C} \$) \\
\text { Discount factor }(\mathrm{C} \$) \\
P V(\mathrm{C} \$)\end{array}$ & $\begin{array}{c}-15,502 \\
1,000 \\
-15,502\end{array}$ & $\begin{array}{l}2,520 \\
0,920 \\
2,318\end{array}$ & $\begin{array}{l}2,664 \\
0,846 \\
2,252\end{array}$ & $\begin{array}{l}2,815 \\
0,788 \\
2,189\end{array}$ & $\begin{array}{l}2,975 \\
0,715 \\
2,127\end{array}$ & $\begin{array}{l}3,144 \\
0,657 \\
2,067\end{array}$ & $\begin{array}{l}3,323 \\
0,605 \\
2,009\end{array}$ & $\begin{array}{l}3,512 \\
0,556 \\
1,952\end{array}$ \\
\hline
\end{tabular}

Tab. 1. Results of the two methods 


\subsection{Alternative prognosis of exchange rates}

Let us suppose that the objective value of the investment is understated, because the expectations in the market regarding the Yen are too pessimistic!

\begin{tabular}{|c|c|c|c|c|c|c|c|c|}
\hline $\begin{array}{l}\text { Year } \\
\text { Period } \\
\text { Time forward rate }\end{array}$ & $\begin{array}{c}2013 \\
0 \\
83,86 \\
\end{array}$ & $\begin{array}{c}2014 \\
1 \\
79,35 \\
\end{array}$ & $\begin{array}{c}2015 \\
2 \\
75,08 \\
\end{array}$ & $\begin{array}{c}2016 \\
3 \\
71,04 \\
\end{array}$ & $\begin{array}{c}2017 \\
4 \\
67,22 \\
\end{array}$ & $\begin{array}{c}2018 \\
5 \\
63,61 \\
\end{array}$ & $\begin{array}{c}2019 \\
6 \\
60,18\end{array}$ & $\begin{array}{c}2020 \\
7 \\
59,95 \\
\end{array}$ \\
\hline \multicolumn{9}{|l|}{ Method I } \\
\hline $\begin{array}{l}\text { Cash flow } \\
\text { Discount } \mathrm{f} \\
P V \text { (Yen) }\end{array}$ & $\begin{array}{c}-1300 \\
1000 \\
-1300,000\end{array}$ & $\begin{array}{c}200 \\
0,972 \\
194,363\end{array}$ & $\begin{array}{c}200 \\
0,944 \\
188,886\end{array}$ & $\begin{array}{c}200 \\
0,918 \\
183,562\end{array}$ & $\begin{array}{c}200 \\
0,892 \\
178,389\end{array}$ & $\begin{array}{c}200 \\
0,867 \\
173,362\end{array}$ & $\begin{array}{c}200 \\
0,842 \\
168,476\end{array}$ & $\begin{array}{c}200 \\
0,819 \\
163,728\end{array}$ \\
\hline \multicolumn{9}{|l|}{ Method II } \\
\hline $\begin{array}{l}\text { Forward rate } \\
\text { Cash flows }(\mathrm{C} \$) \\
P V(\mathrm{C} \$)\end{array}$ & $\begin{array}{r}83,862 \\
-15,502 \\
-15,502\end{array}$ & $\begin{array}{l}77,367 \\
2,585 \\
2,377\end{array}$ & $\begin{array}{l}71,375 \\
2,802 \\
2,369\end{array}$ & $\begin{array}{r}65,847 \\
3,037 \\
2,362\end{array}$ & $\begin{array}{c}60,747 \\
3,292 \\
2,354\end{array}$ & $\begin{array}{c}56,043 \\
3,569 \\
2,346\end{array}$ & $\begin{array}{c}51,702 \\
3,868 \\
2,339\end{array}$ & $\begin{array}{c}47,698 \\
4,193 \\
2,331\end{array}$ \\
\hline
\end{tabular}

Tab. 2. An assumption that the appreciation of the Yen is by $2.5 \%$ faster than the market projections. JPY.

Now according to the method II the NPV value becomes 976 CAD i.e. 81.840

\subsection{Capital investments and currency speculation}

We divide the project into two investments:

1. You borrow 15.502 CAD and you convert them into 1,3 mio JPY;

- Project with zero NPV

2. You invest your proceeds in the construction of a heating equipment factory;

- Negative NPV (-49.230 JPY).

Compare this to another combination of these two investments:

1. You borrow 14.915 CAD and convert them into 1,251 mio JPY;

2. You invest the proceeds in a 7-year bond with a profit 200 .

- Positive NPV in amount of 1.563 CAD, if there is a proper optimistic financial scenario.

Thus, the investment in the factory has two consequences:

- A profit of 1.563 CAD with yen speculations.

- A loss of 587 CAD with the factory.

Net profit $1.563-587=976$ CAD.

\section{Conclusion}

With borrowings abroad it is not easy to make profit. It is necessary to take into account the impact of interest rate parity criteria. Discount rate for the respective currency shall be used, regardless of the time you use it. 
The generally accepted prognosis on the market should be used and you should not have the illusion that you have the "know-how" about the exchange rates.

Using the logic of real options, despite the restriction on individual case studies and decision-making in relation to the development of skills, has proven to be adequate.

In this chapter, we present a new perspective on strategic investment, synthesizing new valuation methods, such as real options and basic concepts from industrial organization. The real option theory is applied in the case of investment in the a factory for heating equipment by using Net Present Value, alternative prognosis of changing exchange rates, capital investments and currency speculations. The results aim at both a professional and an academic level.

Real options analysis provides a tool for the successful integration of market information and strategic engineering and economic decisions. Further studies in this field will ensure that such decisions will be more consistent with the complex business environment and the strategic goals of the company. There is a crucial difference between the valuation of the financial and valuation of real options. The ultimate objective of the financial options valuation is the sale / purchase of securities, while the objective of the analysis of real options should be improvement of the decision-making process. The determination of the exact value of financial options is therefore a prerequisite that must be met. The analysis of real options can be seen as a tool used to support the decision-making process, which is used in combination with traditional methods of valuation of investments, and it is not of a crucial importance to guess the "exact" value of the option.

Our future work will include more cutting-edge ideas and tools on strategic valuation with appropriate industrial application, which will provide critical insight into the potential pitfalls of strategy implementation in investment field.

\section{Acknowledgements}

The authors wish to thank for the support to the R\&D activities at the Faculty of Economics (University of Ljubljana, Slovenia) and to the company ONE (Skopje, Macedonia) in the frame of Telekom Slovenia Group.

\section{References}

*** http://en.wikipedia.org/wiki/Real_options_valuation - Real options valuation (2013), Accessed on: 2013-04-22

Adner, R. \& Levinthal, D. A. (2004). What is not a real option: considering boundaries for the application of real options to business strategy. Academy of Management Review, Vol. 29, No. 1, pp. 74-85

Bollen, N. (1999). Real options and product life cycles. Management Science, Vol. 45, No. 5, pp. 670-684

Bowman, E. H. \& Moskowitz, D. (2001). Real options analysis and strategic decision making. Organization Science, Vol. 12, No. 6, pp. 772-777

Collan, M., Fullér, R. \& Mezei, J. (2009). Fuzzy Pay-Off Method for Real Option Valuation. Journal of Applied Mathematics and Decision Sciences, Vol. 2009 (Open Access, paper No. 238196), pp. 1-14 
Dasu, S. \& Li, L. (1997). Optimal Operating Policies in the Presence of Exchange Rate Variability. Management Science, Vol. 43, No. 5, pp. 705-722

Dixit, A. \& Pindyck, R. S. (1995). The options approach to capital investment. Harvard Business Review, Vol. 73, No. 5-6, pp. 105-115

Howell, S., Stark, A., Newton, D., Paxson, D., Cavus, M., Pereira, J. \& Patel, K. (2001). Real options: Evaluating corporate Investment Opportunities in a dynamic world, Pearson Education Limited, London

Jaimungal, S. \& Lawryshyn, Y. (2012). Managerial Risk Aversion in Real Option Valuation of Early Stage Investments, Proceedings of the $16^{\text {th }}$ Annual International Real Options Conference, London, 13 pages

Kouvelis, P. (1999). Global Sourcing Strategies under Exchange Rate Uncertainty, In Quantitative Models for Supply Chain Management (Eds. Tayur, S., Ganeshan, R. in Magazine, M.), pp. 625-667, Kluwer Academic Publishers, Boston

Kulatilaka, N. \& Trigeorgis L. (1994). The General Flexibility to Switch: Real Options Revisited. The International Journal of Finance, Vol. 6, No. 2, pp. 778-798 Kulatilaka, N. (1993). The value of flexibility: The case of a dual-fuel industrial steam boiler. Financial Management, Vol. 22, No. 3, pp. 271-280

Kyläheiko, K., Sandström, J. \& Virkkunen, V. (2002). Dynamic capability view in terms of real options. International Journal of Production Economics, Vol. 80, No. 1, pp. $65-83$

Luehrman, T. A. (1998). Investment opportunities as real options: getting started on the numbers. Harvard Business Review, Vol. 76, No. 7-8, pp. 61-67

Mauer, D. \& Ott, S. (1995). Investment under uncertainty: The case of replacement investment decisions. The Journal of Financial and Quantitative Analysis, Vol. 30, No. 4, pp. 581-605

Miller, L. T. \& Park, C. S. (2002). Decision Making Under Uncertainty Real Options to the Rescue?. The Engineering Economist, Vol. 47, No. 2, pp. 105-149

Mun, J. (2010). Real Options in Practice, In: Real Options in Engineering Design, Operations, and Management, (Eds. Nembhard, H. B. \& Aktan, M.), CRC Press, Boca Raton

Nembhard, H. B. \& Aktan, M. (2009). Real Options in Engineering Design, Operations, and Management, CRC Press, Boca Raton

Pandza, K., Horsburgh, S., Gorton, K. \& Polajnar, A. (2003). A real options approach to managing resources and capabilities. International Journal of Operations \& Production Management, Vol. 23, No. 9, pp. 1010-1032

Siddiqui, A. (2012). Valuing Managerial Flexibility in Technology R\&D, Proceedings of the $16^{\text {th }}$ Annual International Real Options Conference, London, 26 pages

Smit, H. T. J. \& Trigeorgis, L. (2012). Strategic Investment (Real Options and Games), Princeton University Press, Princeton

Trigeorgis, L. (2002). Real Options - Managerial Flexibility and Strategy in Resource Allocation, MIT Press, Cambridge

Yeo, K. T. \& Qiu, F. (2003). The value of management flexibility - a real option approach to investment evaluation. International Journal of Project Management, Vol. 21, No. 4, pp. 243-250 